
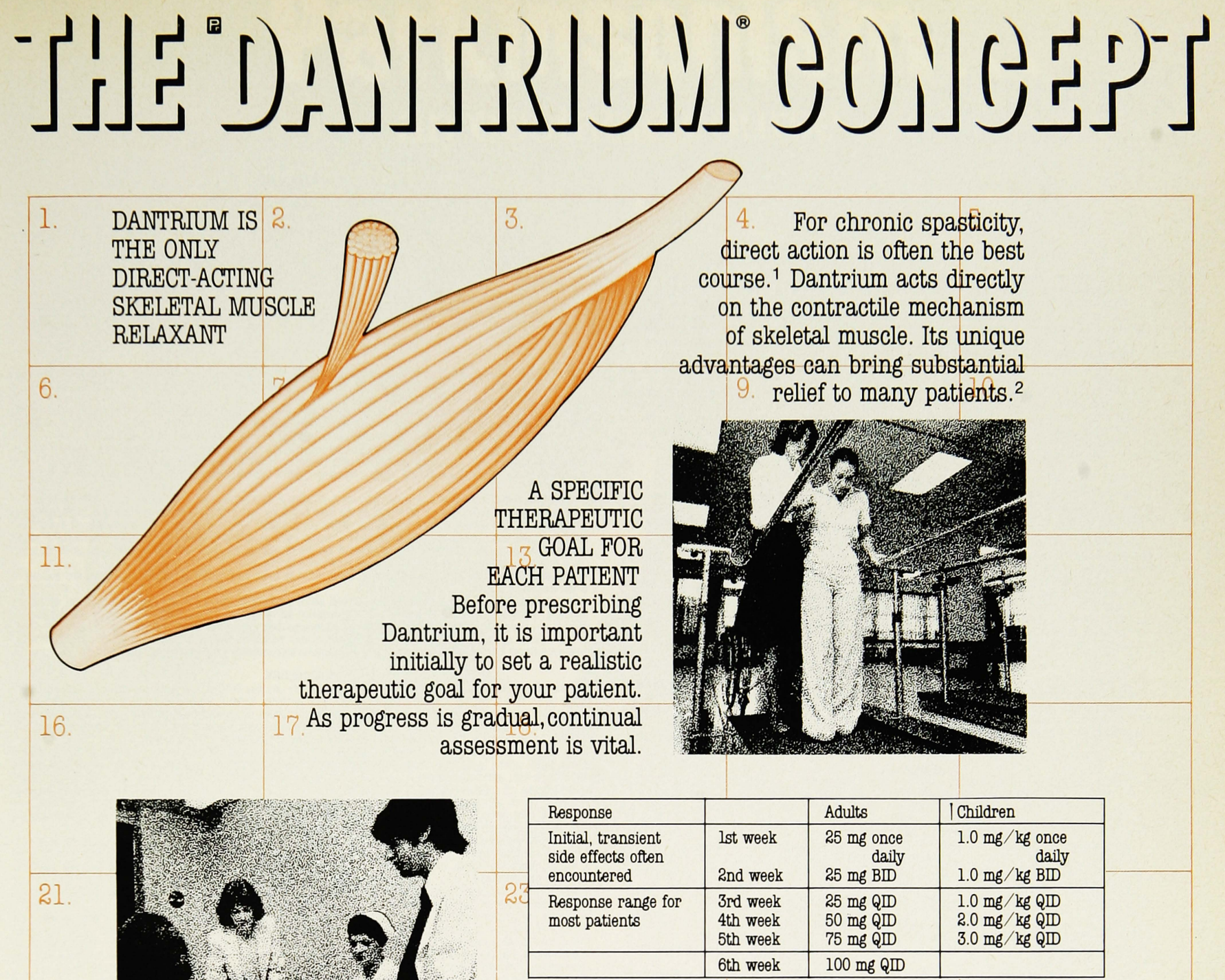

The titration chart shows the flexibility of Dantrium. Dosage is initiated at a low level and titrated according to individual response. If benefits are not evident in 45 days, therapy should be discontinued.

Dantrium avoids persistent sedation, the major limitation of centrally acting muscle relaxants. ${ }^{4,5}$ With Dantrium, drowsiness "... usually disappears within a few days, and it can often be avoided by starting treatment with small dosages to be increased at weekly intervals." ${ }^{4}$ However, it can be used concomitantly with a reduced dosage of a CNS agent to achieve maximum results. It is a major breakthrough in the treatment of chronic spasticity. ${ }^{6}$

\title{
TEAMWORK MAKES THE
}

DIFFERENCE

Every member of the health care team should be aware of the patient's therapeutic goal. The attending specialist, physio/occupational therapists and nursing staff can then work together in a constant feedback situation, all helping with each physical and psychological step forward. Teamwork makes The Dantrium Concept the most viable answer to many forms of chronic spasticity. ${ }^{3}$

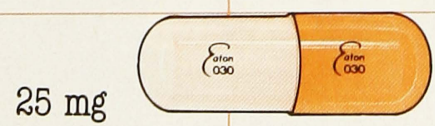

Norwich-Eaton Pharmaceuticals Division of Norwich-Eaton Lid P. Box 2002 Paris Ontario

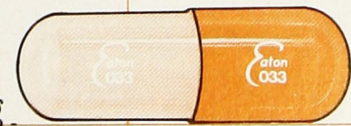

1. Pinder RM, Brogden RN, Speight TM, et al: Dantrolene sodium: a review. Drugs 13:3-24, 1977.

2. Chyatte SB, Basmajian JV: Dantrolene sodium: long term effects in severe spasticity. Arch Phys Med Rehabil 54:311-315, 1973.

3. Chyatte SB, Birdsong JH, Roberson DL: Dantrolene sodium in athetoid cerebral palsy. Arch Phys Med Rehabil 54:365-368, 1973

4. Mayer N, Mecomber SA, Herman R: Treatment of spasticity with dantrolene sodium. Am J Phys Med 52:18-29, 1973.

5. Steinberg FU, Ferguson KL: J Am Geriatr Soc 23:70-73, 1975.

6. Keenan RE, Kolb ME, Horne ML: Collaborative comparison of dantrolene sodium and diazepam. Clinical Therapeutics 1:48-55, 1977 
PHARMACOLOGY
Chemical Name: 1-[5-(p-nutropheny)-furfurylidene] amino hydantoin sodum hydrate.

ACTIONS

Recordings of muscle tensions and electrical activity in both anımal and man suggest that Dantrum has a direct inhibitory effect on the development of contractile tension. Spastic patients receiving Dantruum have shown a $40-70 \%$ reduction in This decrease in contractile tension can be attributed to an effect of Dantrium beyond the myoneural junction. Tota This decrease in contractile tension can be alnuuced change in the contractile state of skeletal muscle is limited in magnitude. The reduction in contractile activity accounts for the ability of Dantrium to diminish spasticity resulting from pathological states associated with a hyperactive stretch refliex.

generalized weakness The peak pharmacologic effect generally occurs in $1 \frac{1}{2} 103$ hours at concentrations of 50 to 75 percent of the peak plasm level. Dantrium is highly bound to plasma proten and, to a lesser extent, red blood cells. Metabolism is rapid via hepatic microsomal enzymes. The major metabolites in humans are a $5-$ hydroxy analog and an acetamino analog. Urinary excretion
of Dantrium and metabolites occurs in an inittally rapid phase $(-1 / 2,2.5103$ hours) followed by a slower phase over a 24 hour of Dantrium and metabolites occurs in an inittally rapis
period. Dantrium is also removed by biliary excretion.

\section{INDICATIONS}

Dantrium is useful in controlling the manifestations of chronic spasticity of skeletal muscle resulting from such conditions as spinal cord injury. cerebral palsy, multiple sclerosis, and stroke, whenever such spasticity results in a decrease in functiona
use of residual motor activity. Dantrium is not indicated in the relief of skeletal muscle spasms due to rheumatic disorders CLINICAL USES

Dantrium has been studied in the treatment of selected patients with moderate to severe skeletal muscle spasticity resulting from stroke. spinal cord injury. cerebral palsy. multiple sclerosis, and other neuropathies. It seems to act directl resistance to stretch clonus, and exagerated reflex posturing interfere with therapeutic exercise programs, utilization o braces, transfer manoeuvres, posture equilibrum, ambulation, and activities of daily living.

Marked reduction or even cessation of spontaneous involuntary movements was observed in many patients receivin Dantrium The extent to which Dantrium may contribute toward improvement in spastccity and activities in dally living can be
tested by withdrawing the drug for 2 to 4 days and observing whether an exacerbation of the patient's condition occurs CONTRAINDICATIONS

Skeletal muscle spasticity without suttable volitional activity (residual motor activity) may be of value in a rehabiltation program aimed toward sustaining upright posture and balance. and may assist a patient's locomotor pattern. Relief of such spasticity would reduce rather than increase function Therefore. in cases where spasticity is utilized to obtain or maintain

Dantrium is contraindicated in patients with compromised pulmonary function, particularly those with obstructive pulmonary
disease.

WARNINGS
DANTRIUM (DANTROLENE SODIUM) HAS THE POTENTIAL TO PRODUCE HEPATOTOXICITY AND SHOULD NOT BE USED IN CONDITIONS OTHER THAN THOSE RECOMMENDED CASES OF FATAL HEPATITIS HAVE BEEN REPORTED IN

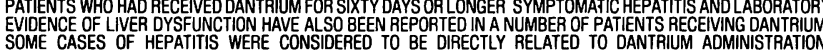
SOME CASES OF HEPATITIS WERE CONSIDERED TO BE DIRECTLY RELATED TO DANTRIUM ADMINISTRATION. OCCUR IN APPROXIMATELY ONE PERCENT OF THE PATIENTS RECEIVING THE DRUG. DANTRIUM MAY EXACERBAT PRE-EXISTING LIVER DYSFUNCTIONS. NO SERIOUS HEPATIC INJURY HAS YET BEEN REPORTED IN PATIENTS
RECEIVING THE DRUG FOR LESS THAN 60 DAYS. ALTHOUGH LIVER ENZYME ELEVATIONS HAVE OCCURRED RISK OF

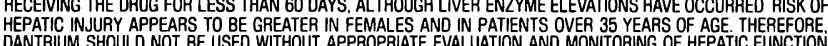
BEFORE AND THROUGHOUT TREATMENT. INCLUDING FREQUENT DETERMINATIONS OF SERUM LIVER ENZYMES.
A TRIAL ADMINISTRATION OF DANTRIUM IS RECOMMENDED AND IF AFTER 45 DAYS NO OBSERVABLE BENEFIT IS A TRIAL ADMINISTRATION OF DANTRIUM IS RECOMMENDED AND IF AFIER 45 DAYS NO OBSERVABLE BENEFIT IS
EVIDENT. DANTRIUM SHOULD BE DISCONTINUED. THE LOWEST POSSIBLE EFFECTIVE DOSE FOR THE INDIVIDUAL PATIENT SHOULD BE PRESCRIBED.
TOXICITY STUDIES N ANIMALS PROVIDED EVIDENCE OF LOW-GRADE CARCINOGENIC ACTIVITY OF DANTRIUM IN THE RAT (SEE SECTION ON TOXICOLOGY). IN VIEW OF THE ANIMAL FINDINGS, POTENTIAL CARCINOGENICITY IN HUMANS CANNOT BE DISREGAROED. THEREFORE, THE POTENTIAL BENEFITS OF THE DRUG SHOULD BE WEIGHED TO WHETHER THE PATIENT HAS RESPONDED TO OTHER MEEICATION AND TO THE BENEFITS OF THE TRIAL PATIENT THE DEGREE OF DISABILITY AND LIIE EXPECTANCY SHOULD ALSO BE CONSIEERED. LONG TERM EFFICACY
AND OTHER ASPECTS OF THE LONG TERM SAFETY OF DANTRIUM HAVE NOT YET BEEN ESTABLISHED. Use In Children: In view of the preceding warning. It is particularly important to assess risk acceptability before Dantrium is used in pediatric patients Since there is insufficient experience with the use of Dantrium in young children (under 5 years of age), the drug is usually not recommended in this age group

in in Pregnancy: The satety of Dantrium in women who are or who may become pregnant has not been established and child. Dantrium should not be used in nursing mothers.
and

\section{PRECAUTIONS}

Although subjective weakness attributable to Dantrium is usually transient. some patients feel excessively weak as long a Dantrium therapy is continued. Such patients may not be able to manipulate rehablitation devices such as wheelcharrs crutches, braces, walkers, or canes. Careful attention should be given to patients utilizing these devices. Dantrium should

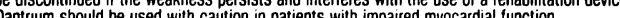

Patients should be instructed not to drive a motor vehicle or participate in a hazardous occupation during the first week of Dantrium therapy. Although the primary pharmaccologic effect of Dantrium is exerted directly on skeletal muscle, an apparent transient CNS effect also may exist. Therelore. caution should be exercised in the concomitant administration of tranquilizing agents
Although photosensitization has not been a problem in clinical trials of Dantrium It is possible that in some subjects the drug might evoke a phototoxic response.
The possibility of cross-sensitivity with compounds of related chemical structure exists; however, no such reactions were The possibility of cross-sensitivity with compounds of related chemical structure exists; however, no such reactions were
reported in extensive clinical trials.
in long-term therapy. periodic clinical laboratory evaluation of organ systems, including haematopoietic, renal, and hepatic studies, should be performed.

\section{ADVERSE REACTIONS}

Side effects most frequently reported were drowsiness, weakness, dizziness, malaise. latigue and diarrhea Less commonly reported effects are listed by systems.

Gastrolntestinal: constipation, anorexia, gastric irritation and bleeding, abdominal cramps, swallowing difficulty, nausea with or without vomiting and liver failure. nervousness. diplopia, insomnia
Urogenital: increased urinary trequency, crystalluria. difficult erection, urinary incontinence and/or nocturia, difficult

urination and/or urinary retention
Musculoskeletal: myalgia, backache.

Intogumentary: acne-like rash, pruritis, urticaria, eczematoid eruption, abnormal hair growth, sweating

Other: chills, rever, excessive tearing, feeling of sulfocation. ADVISABLE TO PERFORM LIVER FUNCTION TESTS BEFORE AND DURING THERAPY. (SEE WARNINGS). Side effects listed as most frequently occurring were generally transient and may be avoided with initial low doses and a gradual increase to optimal doses. Diarrhea may be of sufficient severity to warrant temporary or possibly permanent
withdrawal of medication.

\section{SYMPTOMS AND TREATMENT OF OVERDOSAGE}

A single case has been reported of a patient with an 18 -year history of multiple sclerosis who consumed $1600 \mathrm{mg}$ o Dantrfum per day for 13 days (a total of $20,80 \mathrm{mg}$. Other than reeling slightly weaker and "rubbery", ahe patient appeared to
suffer no clinical manilestatlons of overdosage. Liver function values were transiently elevated although the patient did not become jaundiced.

For acute overdosage general supportive measures should be employed, along with immediate gastric lavage. Intravenous fluids should be administered in fairly large quantities to avert the possibility of crystalluria. An adequate airway should be the patient carefully observed. No experience has been reported with dialysis, hence its value in Dantrium overdosag the patient can
is not known.

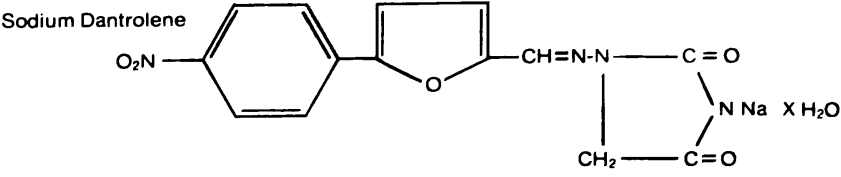

Dantrium causes marked, dose-dependent skeletal muscle relaxation in laboratory anımals with a long duration of action. The pharmacologic profilie of Danirum in animals is unlike neuromuscular blocking agents in that total muscle paralysis and/ur respiratory depression do not occur.

There is a wider margin between doses causing muscle relaxation and doses causing motor incoordination with Dantrium than with centrally acting muscle relaxants Skeletal muscle relaxation is not associated with anaesihetic or analgesic action. Impairment of cornea or pinna reflexes has not been observed in anumals treated with Dantrium.

Various studies both in vivo and in vitro demonstrated the apparent selectivity of action of Dantrium for skeletal muscle There were some non-specific depressant effects seen in several smooth muscle studies and insignificant effects in cardiac animal studies.

it has been shown that Dantrium has no effect on the propagated action potential recorded on the muscle membrane, and the total membrane capaciance is not decreased by the dirug. indicating that it does not disrupt the function of the transverse tubular system, and acts at a point beyond the electrically excitable surface membrane. Evidence obtanned in virto with muscle preparations exposed to calleine, an agent known to cause muscle contractions by releasing internal Catt stores
in muscle sugoests that Dantrium acts on skeletal muscle by altering the Catt release mechanisms. Such an action in muscle, suggests that Dantrium acts on skeletal muscle by altering the Catt release mechanisms. Such an action could explain the apparent specitictty of Dantrium for skeletal muscle.
Animal studies have indicated that Dantrium is metabolized by hydrolysis. mydroxylation. nitro reduction and acetylation Animal studles have indicated that Dantrium is metabolized by hydrolysis. hydroxylation. mio redction and acetlation Four corresponding metabolites have been identifted which probably do not contribute sugniticantly to the activity of $40 \%$ of an I.V dose of Dantrium is excreted as the hydroxylated metabolite in bile whereas only $1 \%$ of the dose is excreted in this manner by the ran High billary concentrations of this metabolite have also been tound in the Rhesus monkey.
Total excretion of known metabolites in the urine is estumated at approximately $3 \%$ in the dog and approximately $10 \%$ in the rat. TOXICOLOGY

The oral $\mathrm{LD}_{50}$ of dantrolene sodium in newborn. Sprague-Dawley rats was $2902 \mathrm{mg} / \mathrm{kg}$ No young adult rats were killed wrth doses up to $18,000 \mathrm{mg} / \mathrm{kg}$. Pertinent clinical signs were inactivity, lethargy. weakness, gasping. diarriea. yellownng of pelvic necrosis occurred in kidneys. No deaths occurred within 48 hours in adult rabotts and mice. with oral doses up to 8 or $9 \mathrm{~g} / \mathrm{kg}$, respectively. Crystals were observed in ine urinary and the gall bladders of rabbits

Three subacute toxicity studies were conducted in rats with oral doses up $10500 \mathrm{mg}$ of dantrolene sodum/ $\mathrm{kg}$ for 28 days and up to $86 \mathrm{mg} / \mathrm{kg}$ for 88 days. Body weight gains were reduced significantly by doses of $43.8 \mathrm{mg} \mathrm{kg}$. Relative kioney
and liver weights were increased by doses of $15.5 \mathrm{mg} / \mathrm{kg}$ and absolute liver weights by $86 \mathrm{mg} / \mathrm{kg}$ for 88 days. Increased and liver weights were increased by doses of $15.5 \mathrm{mg} / \mathrm{kg}$ and absolute liver weights by $86 \mathrm{mg} / \mathrm{kg}$ for 88 days. Increased serum alkaline phosphatase and SGOT Occurred with doses of $625 \mathrm{mg} / \mathrm{kg}$. Rats dosed with $500 \mathrm{mg} / \mathrm{kg}$ lor 28 days had
increased serum alkaline phoshatase. SGOT, tasting plasma glucose. plasma urea nitrogen. serumm creatinine. and
decreased urine specific gravity. Renal tubules were plugged by drug crystals. and tubular dilatation. degeneration. Chronic toxicity studies were conducted in Beagle dogs for 1 year. Oral doses of $15 \mathrm{mg} / \mathrm{kg} /$ day produced no detectable increasing doses $190 \mathrm{mg} / \mathrm{kg}$ for the first 206 days followed by $180 \mathrm{mg} / \mathrm{kg}$ tor 14 days and $360 \mathrm{mg} / \mathrm{kg}$ for an additional 82 days) caused marked loss in body weight. increased SGOT activity and BSP retention. normocytic orthochromic after discontinuation of drug administration.

A one-year oral toxicity study also was conducted with Rhesus monkeys Inittal doses of 0.15 .30 and $60 \mathrm{mg}$, $\mathrm{kg}$ were used Because of the lack of clinical toxicity during the first 6 months, the dosage levels were doubled at the end of the
first 6 months. At 9 months. the dosage level for the high dose group was again doubled and these animals were then

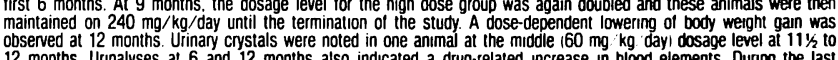
12 months. Urinalyses at 6 and 12 months also indicated a drug-related increase in blood elements Durning the last a higher serum alkaline phosphatase, a high SGOT level in the two high dosage levels. and relatively lower serum creatinine levels in the high dosage groups were noted. Chronic hepatic cholangitis was observed at necropsy in some mid and high dosage level animals.
Dantrolene sodium was administered in the diet to mature Sprague-Dawley rats for 18 months at levels of 15,30 and $60 \mathrm{mg} / \mathrm{kg}$ daily. Treated rats showed a lower body weight gain compared to controls and damage to the liver. There was an $60 \mathrm{mg} / \mathrm{kg}$ daily dosage levels) were increased incidences of bile duct cystadenomas, and increased mammary tumors in females. At the $60 \mathrm{mg} / \mathrm{kg}$ daily level the number of metastasizing mammary adenocarcinomas in female rats was increased signiftcantly; anisotropic urinary crystals were found in both male and female groups.
Because of these findings, lifetime tumorigenesis studies were conducted in Sprague-Dawley and Fischer 344 rats. The treated Sprague.-Dawley rats received dantrolene sodium in the diet at levels of 15.30 and $60 \mathrm{mg} / \mathrm{kg}$ dally for 18 months and the Fischer 344 rats received the same levels for 20 months. The animals subsequently were mantane

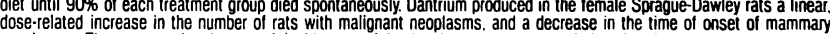

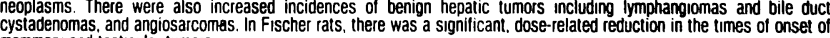
mammary and testicular tumors.

A two year tumorigenesis study was conducted in Swiss mice (CD:-1 HaM ICR). Dantrolene sodium was ted to mice at levels of 15,30 and $60 \mathrm{mg} / \mathrm{kg} /$ day lor 15 months and then the mice were maintained on a standard diet for 9 additional

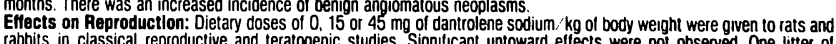
14 pops classical reproductive and teratogenic studies Signilicant untoward effects were nol observed. One litter of Malformations a rat treated with $45 \mathrm{mg}$ of dantrolene sodium/ kg between days 6 to 15 of gestation had 6 malformed pups.
mils, a short upper jaw, and renal agenesis Two pups in another litter had unilateral
microphthalmia An association with treatment was considered doubtiul.

\section{DOSAGE AND ADMINISTRATION}

Prior to the administration of Dantrium, consideration should be given to the potential response to treatment. A decrease in spasticity sufficient to allow a daily function not otherwise allainable should be the therapeutic goal of treatment with It is important to establish a therapeutic goal (regain and maintain a specific function such as therapeutic exercise propram. utitization of braces. transfer manoeurres. elc.) belore beginning Dantrium therapy. Oosage should be increased Usual bosage: It is important that the dosage be titrated and individualized for maxımum effect The lowest dose compatible with optimal response is recommended

Adults: Begin therapy with $25 \mathrm{mg}$ once daily increase to $25 \mathrm{mg}$ two three or four times daily and then. by increments of $25 \mathrm{mg}, 10100 \mathrm{mg}$ two, three, or four times daily. if necessary. Each dosage level should be maintained for lour to seven Only occasionally will a dose greater than 100 mo four times daily be required in which case the dose can be increased gradually, depending on tolerance. up $10200 \mathrm{mg}$ lour times daily. received maximal beneflit without adverse elfects.

Children: A simillar approach should be uttilized, starting with $1.0 \mathrm{mg} / \mathrm{kg}$ of body weight once daily: this is increased to $1.0 \mathrm{mg} / \mathrm{kg}$ two, three, or tour times daily and then, by increments of $0.5 \mathrm{mg} / \mathrm{kg}$. up $103.0 \mathrm{mg} / \mathrm{kg}$ two. three. or four times should be increased only II the therapeutic goal has not been attained Doses higher than $100 \mathrm{mg}$ lour times daily
s.

DOSAGE FORMS

Dantrium is available in opaque orange and brown capsules of $25 \mathrm{mg}$ (coded "Eaton 030" in black), and opaque orange and brown capsules of $100 \mathrm{mg}$ (coded "Eaton 033 " in white). They are supplied in bottles containing 100 and 500 capsules. Norwich-Eaton Pharmaceuticals

Division of Norwich-Eaton Led

P.O. Box 2002

Paris, Ontario
N3L $3 G 6$ 


\section{Prakinsonismu.. an obstacle course}

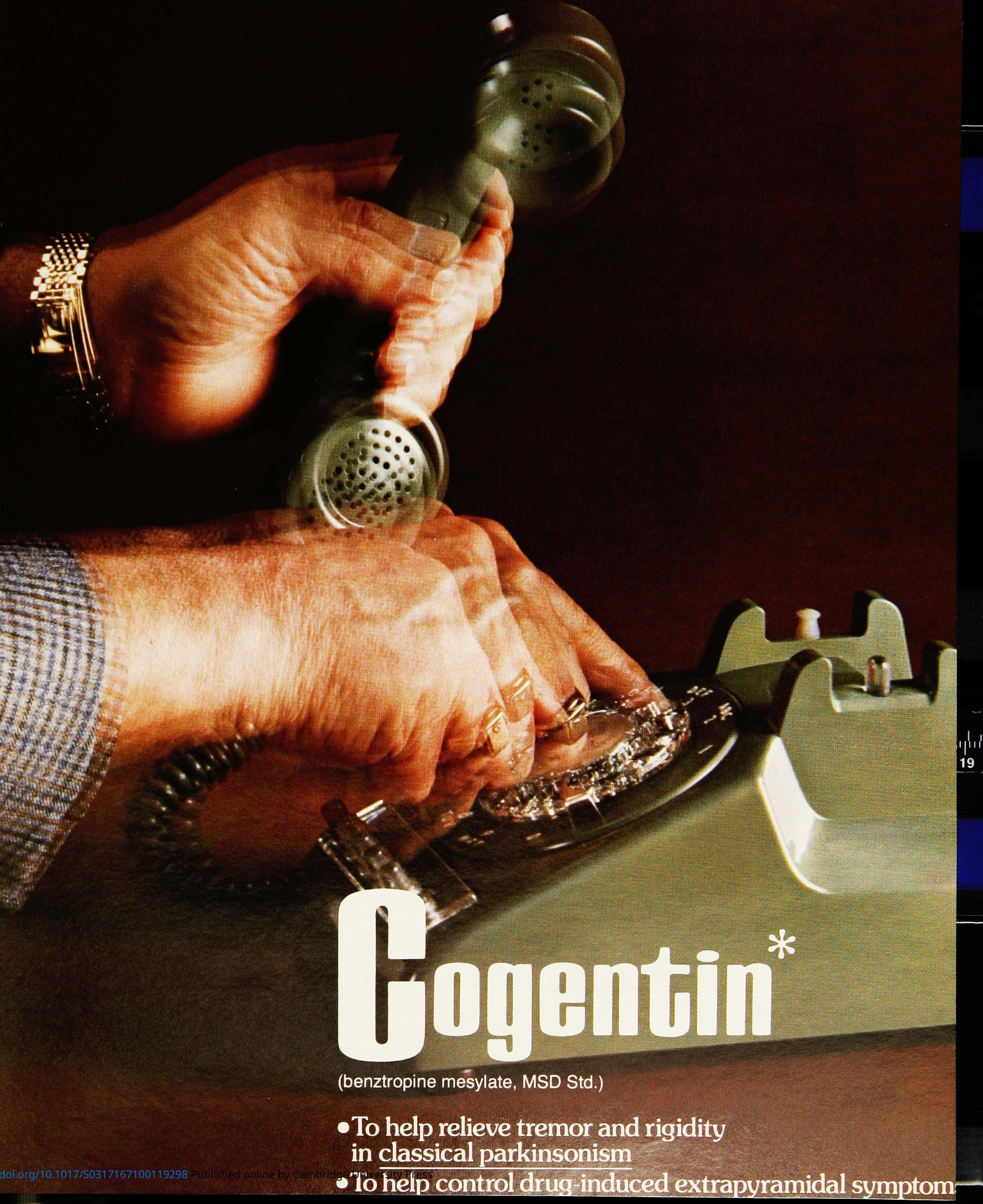


Available as: $2 \mathrm{ml}(1 \mathrm{mg} / \mathrm{ml})$ injection

$2 \mathrm{mg}$ tablets

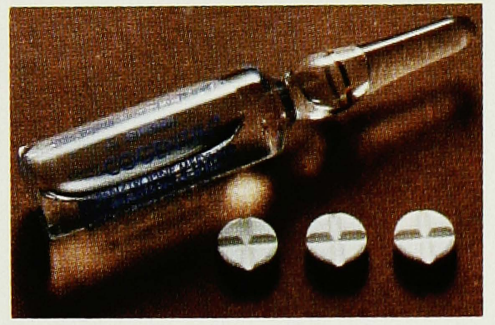

\section{Indications}

In the symptomatic treatment of all etiological groups of parkinsonism arteriosclerotic, postencephalitic, idiopathic, and drug-induced. Therapy is directed towards control of disturbing symptoms to permit maximum integration of functions and minimum discomfort.

Drug-Induced Parkinsonism

COGENTIN* relieves manifestatıons of parkınsonism that may appear during treatment with reserpine and phenothıazine derivatives.

\section{Dosage Summary}

COGENTIN* should be given in tablet form where at all possible, otherwise it may be given

intramuscularly or intravenously. As COGENTIN* has cumulative action, it should be initiated in a small amount, and increased gradually by increments of $0.5 \mathrm{mg}$ at 5 or 6 day intervals, to a maximum of $6 \mathrm{mg}$ or until optimal results are obtained without excessive side effects

Arteriosclerotic, Idiopathic and Postencephalitic Parkinsonism The usual oral daily dosage is 1 to $2 \mathrm{mg}$, ranging between 0.5 to $6 \mathrm{mg}$, according to the needs of the patient.

Drug-Induced Parkinsonism The recommended dosage is 1 to $4 \mathrm{mg}$ once or twice a day orally or parenterally

\section{Contraindications}

Children under 3 years of age. Use with caution in older children. In the presence of glaucoma.

\section{Warnings}

Safe use in pregnancy has not been established

Benztropine mesylate may impair mental and/or physical abilities required for performance of hazardous tasks, such as operating machinery or driving a motor vehicle.

\section{Precautions}

Since COGENTIN* has a cumulative action, maintain continued supervision. Use with caution in patients with a tendency to tachycardia or patients with prostatic hypertrophy. Dysuria may occur Glaucoma is a possibility. In large doses, weakness and inability to move muscles, mental confusion, excitement with occasional visual hallucination may occur. Occasionally, intensification of mental symptoms in patients receiving phenothiazines or reserpine. The psychotogenic potential of antiparkinsonian drugs should be considered when planning the management of patients with mental disorders These patients should be kept under observation, especially at the beginning of treatment and if dosage is increased. Advise patients to report gastroıntestinal complaints promptly when COGENTIN* is administered with other drugs with anticholinergic activity (e.g., phenothiazines, tricyclic antidepressants). Not recommended in patients with tardive dyskınesia As COGENTIN* may produce anhidrosis, use with caution in patients with abnormal sweating and decrease dosage if evidence of impaired ability to maintain body heat equilibrium is evident.

\section{Adverse Reactions}

May be anticholinergic or

antihistaminic in nature. Dry mouth, blurred vision, nausea, nervousness, vomiting, constipation, numbness of

fingers, listlessness, depression, allergic reactions, e.g., skin rash Reduce dosage or discontinue temporarily if adverse reactions, such as dry mouth, nausea, vomiting, or skin rash, are overly troublesome

Full prescribing information avallable on request

\section{How Supplied}

Ca 3172 - Tablets COGENTIN

$2 \mathrm{mg}$ white, flat, discoid-shaped quarter-sected, compressed tablets, are supplied in bottles of 100 and 1000 .

Ca 3275 - Injection COGENTIN* is a clear, colorless solution, available in $2 \mathrm{ml}$ ampuls, each ampul containing $2 \mathrm{mg}$ of benztropine mesylate

CGT-8-CA-527-JA

\section{MSD | MERCK}




\section{SILVER JUBILEE PSYCHIATRIC RESEARCH MEETING}

A multidisciplinary psychiatric research meeting will be held on May 9-11, 1979, in Saskatoon. Entitled "FROM MOLECULES TO COMMUNITY: MULTIFACETED MENTAL HEALTH RESEARCH", the meeting is sponsored by the Psychiatric Research Division of the Saskatchewan Department of Health and the Department of Psychiatry, University of Saskatchewan. The meeting will mark the 25th Anniversary of the establishment of Psychiatric Research as an integral part of the programme of the Saskatchewan Department of Health, and in honour of this occasion, a number of distinguished guest speakers will participate and discuss recent advances in biological, clinical and psychosocial research in psychiatry.

Additional information can be obtained from:

D. G. Irvine,

Psychiatric Research Division, University Hospital,

Saskatoon, Saskatchewan S7N 0W8. 

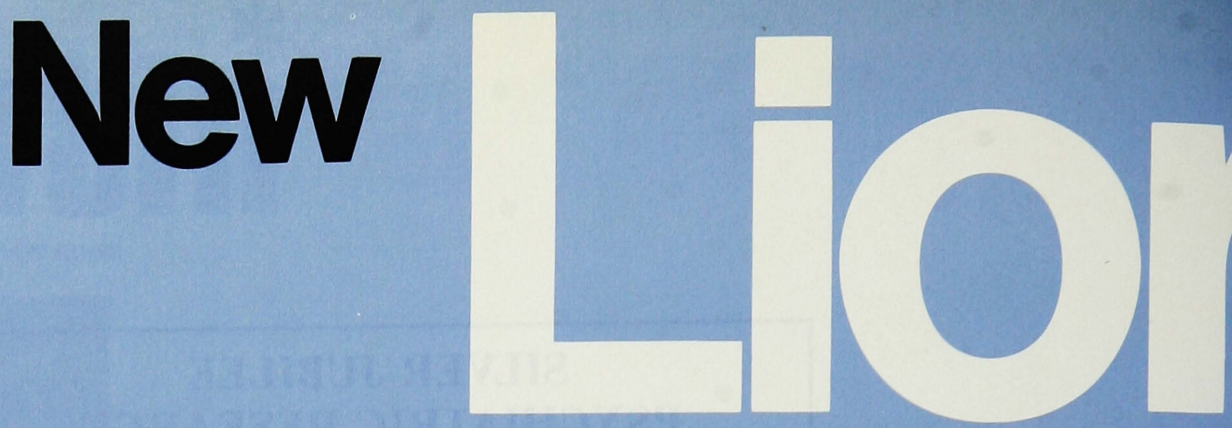

\section{baclofen}

\section{for spasticity resulting from multiple sclerosis, spinal cord injury, and spinal cord diseases.}

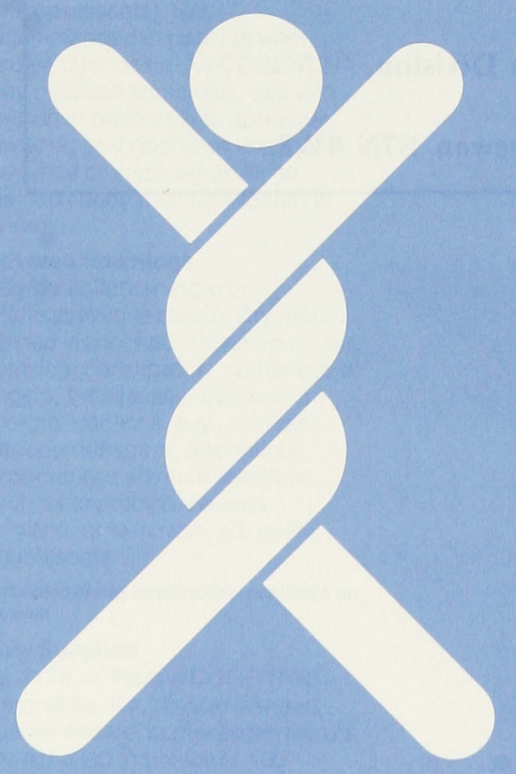

\section{Acts primarily at the spinal level}

Lioresal is capable of inhibiting both monosynaptic and polysynaptic reflexes at the spinal level, possibly by hyperpolarization of the afferent terminals. However, the precise mechanism of action is not fully known. Actions at supraspinal sites may also occur and contribute to the clinical effect. 


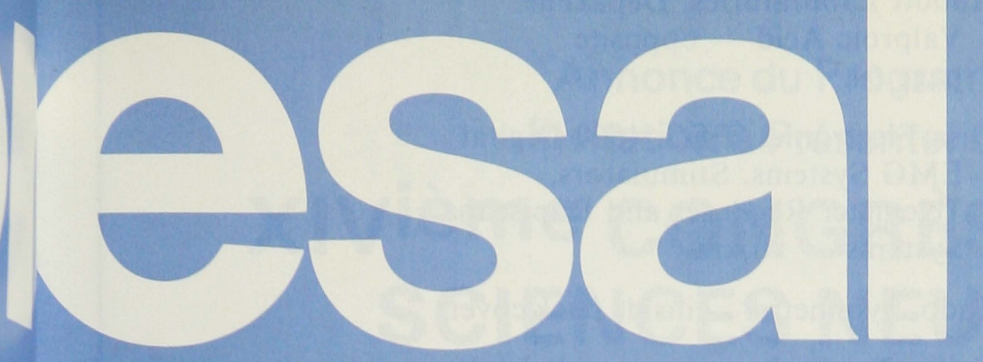

\section{Effective and safe}

Results of a four-week, double blind crossover study of 22 patients showed 72 percent of 18 patients with spontaneous daytime spasms had a reduction in the frequency when treated with Lioresal. Furthermore, a reduction in severity amplitude, and duration of remaining spasms was also reported in patients treated with Lioresal.

Figure 1. Average daily number of spasms during the last week of baclofen and placebo treatment periods in the 18 patients with spontaneous daytime spasms. (From Duncan et al')
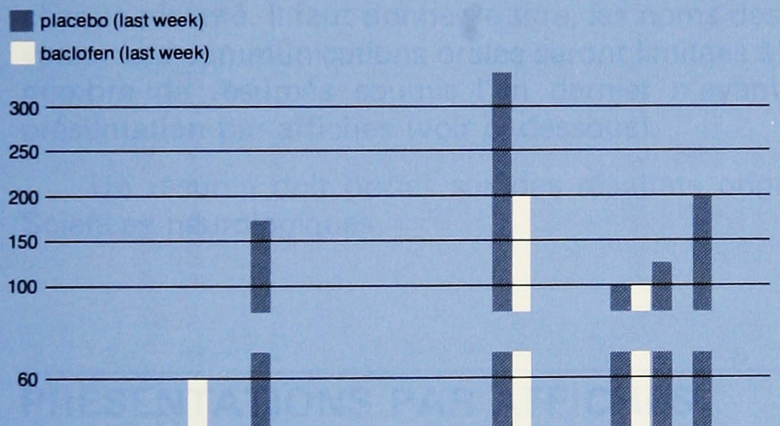

When compared with placebo and diazepam in a double-blind study, Lioresal proved to be effective in reducing the number of spasms in $50 \%$ of patients who had developed tolerance to diazepam. ${ }^{2}$

In one study of 14 patients with spasticity, "Baclofen caused less sedation than would have been expected from comparable doses of diazepam but it did nevertheless have a tranquilizing effect..."3

And in one double-blind study, "No serious side effects developed and there were no signs of even transient bone marrow, liver, kidney, or gastrointestinal toxicity."1 A few cases of increased SGOT, elevated alkaline phosphatase and elevated blood sugar have been reported but are not clinically significant. Gastrointestinal and other side effects also have been reported but generally do not persist.

\section{Facilitates physical therapy}

By relieving painful spasms Lioresal may allow more active physical therapy and daily function.

The advantages of improvement in resistance to passive movement noted in patients treated with Lioresal included more comfortable positioning and easier transfers and nursing.'

Effect of treatment on resistance to passive movement (Adapted from Duncan et $\mathrm{al}^{1}$ )

\begin{tabular}{llc} 
Stage & Baclofen & Placebo \\
\hline Improved & $11(55 \%)$ & $1(5 \%)$ \\
Worsened & $0(0 \%)$ & $0(0 \%)$ \\
Unchanged & $9(\mathbf{4 5} \%)$ & $19(95 \%)$ \\
\hline Total & 20 & 20
\end{tabular}


Lioresal@baclofen

Brlef Prescribing Information

Indlcations and clitit

Lloresal (baclofen) is useful for the alleviation of signs

and symptoms of spasticity resulting from multiple

sclerosis.

Lloresal may also be of some value in patients with spinal cord injuries and other spinal cord diseases.

Contraindication

Hypersensitivity to Lloresal (baclofen).

Abrupt Drug Withdrawal: Following abrupt withdrawal of Lloresal (baclofen), visual and auditory hallucinations, confusion, anxiety with tachycardia and sweating,

insomnia, and worsening of spasticity have occurred.

Therefore, except for serious adverse reactions, the dose should be reduced slowly when the drug is discontinued. Impaired Renal Function: Because Lioresal is primarily given with cautiod through the kidneys, it should be given with caution, and it may be necessary to reduce fited patients with stroke. The patients have a bene-

shown poor tolerabilty to the drug. Pregnancy: Safe use - of Llolished. High incidence of abdominal hernias in the fetuses of rats of ossification defects in those of rats and rabbits. There fore, the drug should be administered to pregnant patients, or women of child-bearing potential only when, in the judgment of the physician, the potential benefits outweigh the possible hazards.

Precautions

Safe use of Lioresal (baclofen) in children under age 12 has not been established and it is, therefore, not recom mended for use in children.

Because of the possibility of sedation, patients should be cautioned regarding the operation of automobiles or dangerous machinery, and activities made hazardous by decreased alertness. Patients should also be cautioned that the central nervous system effects of Lioresal may be additive to those of alcohol and other CNS depressants. Lioresal should be used with caution where spasticity is utilized to sustain upright posture and balance in locomotion, or whenever spasticity is utilized to obtain increased function.

Extreme caution should be exercised in patients with epilepsy or a history of convulsive disorders. In such patients, the clinical state and electroencephalogram should be monitored at regular intervals during therapy, as deterioration in seizure control and EEG has been reported occasionally in patients taking Lioresal. Caution should be used in treating patients with peptic ulceration, severe psychiatric disorders, elderly patients with cerebrovascular disorders, and in patients receiving antihypertensive therapy.

It is not known whether Lloresal is excreted in human milk. As a general rule, nursing should not be undertaken while a patient is on a drug since many drugs are excreted in human milk.

The most common adverse reactions associated with Lioresal (baclofen) are transient drowsiness, dizziness, weakness and fatigue. Others reported: Neuropsychiatric: Headache $(<10 \%)$, insomnia $(<10 \%)$, and, rarely, atric: Headache $(<10 \%)$, insomnia $(<10 \%)$, and, rarely, tions, paresthesia, muscle pain, tinnitus, slurred speech, coordination disorder, tremor, rigidity, dystonia, ataxia, blurred vision, nystagmus, strabismus, miosis, mydriasis, diplopia dysarthria epileptic seizures Cardiovascular: Hyponsion $(<10 \%$ ) rare instances of dyspea tion, chest pain, syncope Gastrointestinal: Nausea, (approx 10\%), constipation $<10 \%$ ) and, rarely, (approx. 10\%), co nstipation (<10\%), and, rarely, dry vomiting, diarrhea and positive test for occult blood in stool. Genitourinary: Urinary frequency $(<10 \%)$ and rarely, enuresis, urinary retention, dysuria impotence, inability to ejaculate, nocturia, hematuria. Other: Instances of rash, pruritus, ankle edema, excessive per-

spiration, weight gain, nasal congestion.

Some of the CNS and genitourinary symptoms reported may be related to the underlying disease rather than to drug therapy.

The following laboratory tests have been found to be abnormal in a few patients receiving Lloresal: SGOT, alkaline phosphatase and blood sugar (all elevated). Dosage and Adminlstration

The determination of optimal dosage of Lioresal (baclofen) requires individual titration. Start therapy at a low dosage and increase gradually until optimum effect is achieved (usually between $40-80 \mathrm{mg}$ daily)

The following dosage titration schedule is suggested

$5 \mathrm{mg}$ t.i.d. for 3 days

$10 \mathrm{mg}$ t.i.d. for 3 days

$15 \mathrm{mg}$ t.i.d. for 3 days

$20 \mathrm{mg}$ t.i.d. for 3 days

Thereafter additional increases may be necessary but the total daily dose should not exceed a maximum of $80 \mathrm{mg}$ daily ( $20 \mathrm{mg}$ q.i.d.).

The lowest dose compatible with an optimal response is recommended. If benefits are not evident after a reasonable trial period, patients should be slowly withdrawn rom the drug (see Warnings).

Avallablity! Lioresal (bacloten) $10 \mathrm{mg}$ tablets.

with identification code 23 below the monogram. reverse side. Available in bottles of 100 tablets.

References

. Duncan, G. N., Shahani, B. T., and Young, R. R.: An evaluation of baclofen treatment for certain symptoms in patients with spinal cord lesions. Neurology, (May) 1976, pp. 441-446.

Jones, R. F.: Lioresal in the control of spasticity. Spasticity. . A topical sun

3. McLellan, D. L.: Effects of baclofen upon monosynaptic and tonic vibration reflexes in patients with spasticity. J. Neurol. Neurosurg. Psychiatry, 36(4): 555-560,

(Aug.) 1973.

Geigy Dorval, Qué. H9S 1B1

\section{INDEX TO ADVERTISEMENTS}

Abbott Laboratories, Depakene, Valproic Acid - opposite page 64.

Disa Electronics, EEG, 1500 Digital EMG Systems, Stimulators, Telemeter Recorder and Rapiscan Systems - xii,xiii

Endo, Symmetrel - inside back cover

Geigy, Tegretol - xiv, outside back cover, Lioresal - xxii

Grass Instruments - Evoked Response System and Optional Stimulators - ii

Hoffmann-La Roche, Rivotril - i Prolopa - iv

Merck Sharp \& Dohme, Sinemet $-\mathrm{x}$ Cogentin - xix

Norwich-Eaton, Dantrium - xvii

Parke Davis, Dilantin, Zarontin - vi

Sandoz Pharmaceuticals, Headache Therapy - opposite page 80 .

Unimed, Serc - ix 


\section{Annonce du Programme Scientifique et Invitation à Présenter des Résumés pour le XIVième CONGRĖS CANADIEN DES SCIENCES NEUROLOGIQUES

\author{
du 13 au 16 juin 1979
} \\ Hotel Nova Scotian, Halifax, Nouvelle-Écosse}

Les communications scientifiques seront présentées les 14, 15, 16 juin 1979. Une journée de Neurologie des enfants et le cours précédant le Congrès auront lieu le 13 juin 1979.

En plus des membres des trois sociétés fondatrices, les membres de la Société des sciences neurologiques assisteront ou participeront au Congrès.

\section{RÉSUMÉS DES ARTICLES SCIENTIFIQUES}

Les résumés soumis en vue de leur présentation comme communications scientifiques doivent être dactylographiés, à simple interligne, dans la zone lignée au verso. Un résumé doit présenter en moins de 200 mots les données et conclusions essentielles. On demande l'original et six (6) copies de chaque résumé. II faut donner le titre, les noms des auteurs et leurs villes de travail comme indiqué au verso. Les communications orales seront limitées à 10 minutes plus 5 minutes de discussion. Un grand nombre de résumés soumis l'an dernier n'ayant pu être présentés, on inaugure cette année la présentation par affiches (voir ci-dessous).

Un résumé doit porter sur des résultats originaux et sera publié dans le Journal canadien de Sciences neurologiques.

\section{PRÉSENTATIONS PAR AFFICHES}

Sauf demande à l'effet du contraire, tous les résumés soumis seront considerés pour la présentation par affiches (voir formule au verso). Les présentations par affiches seront organisées de façon à permettre des discussions avec leurs auteurs. Certaines présentations par affiches seront visibles pendant toute la durée du Congrès. Les résumés des présentations par affiches seront publiées comme ceux des communications orales.

\section{SOUMETTRE LES RÉSUMÉS À:}

Dr. H.B. Dinsdale

Scientific Program

Division of Neurology

78 Barrie Street

Kingston, Ontario

K7L 3J7

au plus tard le lundi 5 mars. Les résumés reçus après cette date ne seront pas considerés. 


\title{
Notice of Scientific Program and Call for Abstracts for the XIV CANADIAN CONGRESS OF NEUROLOGICAL SCIENCES
}

\author{
Hotel Nova Scotian, Halifax, Nova Scotia \\ June 13th-16th, 1979
}

The Scientific Program will be held June 14th, 15th and 16th, 1979.

A day in Child Neurology and the Pre-Congress Course will be held on June 13th, 1979.

In addition to the three founding societies of the Congress there will be attendance and participation by members of the Society for Neuroscience.

\section{ABSTRACTS FOR SCIENTIFIC PAPERS}

Abstracts to be submitted for consideration for the Scientific Program must be typed, single spaced, within the ruled area on the reverse side of this announcement. Abstracts should summarize data and conclusions and contain not more than 200 words. Seven (7) copies of the Abstract (original and 6 photocopies) are required. The style for the title and authors' names and cities is provided at the bottom of the reverse side. Papers accepted for platform delivery will be allotted 10 minutes for presentation and 5 minutes for discussion. Because of the large number of submissions last year, many of which could not be included in the program, poster sessions are being introduced this year (see below).

Abstracts should report original material and will be published in the Canadian Journal of Neurological Sciences.

\section{POSTER SESSIONS}

All abstracts will be considered for poster presentation unless a request is made not to do so (see reverse side). Special arrangements will be made to allow time for poster presentations when presenters will be available for discussion. Some invited posters will be available throughout the entire duration of the Congress. Abstracts of poster presentations will be published in the same fashion as platform presentations.

\section{ALL ABSTRACTS SHOULD BE MAILED TO:}

Dr. H.B. Dinsdale

Scientific Program

Division of Neurology

78 Barrie Street

Kingston, Ontario

K7L 3J7

The deadline for receipt of abstracts is Monday, March 5, 1979. Abstracts received after that date will not be considered by the Scientific Program Committee. 